\title{
EKSISTENSI KETERANGAN AHLI SEBAGAI ALAT BUKTI DALAM SISTEM PERADILAN PIDANA DI INDONESIA
}

\author{
Hanafi \\ Pusat Riset dan kajian HAM Kota Malang \\ Email : hanafioke1994@gmail.com
}

\begin{abstract}
Abstrak
Dalam pemeriksaan perkara pidana, seorang ahli yang dihadirkan dalam persidangan memerlukan pula pengetahuan secara hukum tentang kedudukan dan ruang lingkup keterangannya sebagai ahli dalam sebuah persidangan. Seorang ahli dalam memberikan keterangan dalam satu persidangan perkara pidana harus memiliki pemahaman yang memadai atas keterangan yang akan diberikannya, karena bisa jadi ahli terjebak memberikan keterangan seolah-olah keterangan yang diberikannya tidak obahnya keterangan "saksi". Kemungkinan ahli memberikan keterangan layak keterangan seorang saksi bisa berasal dari diri ahli sendiri, bisa pula terjadi karena ketidakmapuannya memilah dan memahami pertanyaan yang diajukan hakim, penuntut umum maupun penasehat hukum.
\end{abstract}

Kata kunci: keterangan saksi, persidangan, pengetahuan

\begin{abstract}
In the examination of a criminal case, an expert presented in the proceedings requires legal knowledge of the position and scope of his testimony as an expert in a trial. An expert in giving testimony in a trial of a criminal case must have sufficient understanding of the information to be given, as it may be that the expert is trapped giving information as if the information he provided does not obey the "witness" description. The possibility of the expert giving the information worthy of the testimony of a witness may come from his or her own expert, may also occur because of his incompetence to sort and understand the questions posed by the judge, prosecutor and legal counsel.
\end{abstract}

Keywords: testimony of witnesses, trial, knowledge

\section{PENDAHULUAN}

Negara Indonesia adalah negara hukum, hal ini sesuai dengan ketentuan Pasal 1 ayat (3) Undang-undang Dasar Negara Republik Indonesia 1945. Dalam kenyataannya masyarakat tidak dapat dipisahkan dengan hukum, dimana tingkah laku manusia di dalam setiap pergaulannya tidak boleh bertentangan dengan ketentuan hukum yang berlaku. Hukum memiliki berbagai tujuan, diantaranya yaitu untuk menciptakan ketertiban dan keamanan. Manusia diharapkan untuk berperilaku sesuai dengan ketentuan hukum yang ada agar tercapai ketertiban dan keamanan. Namun, tidak selamanya manusia berperilaku tertib hukum, ada kalanya manusia justru melanggar ketentuan hukum yang berlaku. 


\section{Hurnal Negara dan $\mathcal{X}$ eadilan \\ p-ISSN 2302-7010 e-ISSN 2721-9801}

Terselenggaranya negara hukum sesuai dengan Undang-Undang Dasar 1945 mutlak memerlukan perangkat perundang-undangan yang menjunjung tinggi hak asasi manusia serta menjamin setiap warga negara bersamaan kedudukannya didalam hukum dan pemerintahan itu dengan tidak ada kecualinya. Demikian pula dibidang hukum acara pidana sebagai dasar terselenggaranya peradilan pidana yang adil dan manusiawi dalam negara hukum, dipandang perlu tersedianya perangkat perundang-undangan yang menjamin pelaksanaan penegakan hukum (pidana) sesuai dengan fungsi dan wewenang masing-masing aparatur penegak hukum kearah tegaknya hukum, keadilan dan perlindungan harkat dan martabat manusia, ketertiban, serta kepastian hukum. ${ }^{1}$

Perkembangannya hukum acara pidana di Indonesia dari dahulu sampai sekarang ini tidak terlepas dari apa yang disebut pembuktian, apa saja jenis dan tindak pidananya dapat melewati proses pembuktian. Proses pembuktian merupakan salah satu proses yang paling penting karena tahap tersebut yang membuktikan apakah seseorang yang diduga melakukan tindak pidana benar atau tidak melakukan tindak pidana tersebut.

Pembuktian merupakan masalah yang memegang peranan penting dalam proses pemeriksaan di sidang pengadilan, dimana Jaksa Penuntut Umum yang mendakwakan seseorang dihadapan persidangan, berupaya untuk membuktikan kebenaran dari dakwaannya. Melalui pembuktian, akan ditentukan nasib dari terdakwa. Apabila hasil pembuktian dengan alat-alat bukti yang ditentukan oleh undang-undang tidak cukup membuktikan kesalahan yang didakwakan kepada terdakwa oleh Jaksa Penuntut Umum, maka terdakwa dibebaskan dari hukumannya. Namun, jika kesalahan terdakwa dapat dibuktikan berdasarkan dakwaan dan alat-alat bukti yang sah maka terdakwa dinyatakan bersalah.

Salah satu alat bukti yang terdapat dalam Kitab Undang-Undang Hukum Pidana (KUHAP) Pasal 184 ayat (1) adalah Keterangan Ahli. Keterangan Ahli ini dapat diberikan baik pada waktu pemeriksaan oleh penyidik maupun penuntut umum yang dituangkan dalam bentuk laporan dan dibuat mengingat sumpah pada waktu menerima jabatan atau pekerjaan, ataupun pada saat pemeriksaan di sidang untuk diminta keterangannya dan dicatat dalam berita acara pemeriksaan. Keterangan tersebut diberikan setelah ia mengucapkan sumpah atau janji di hadapan hakim. Apabila suatu pemeriksaan awal tidak dilakukan pemeriksaan ahli dalam suatu perkara, tetapi dalam pemeriksaan di muka sidang ternyata diperlukan pendapat dari seorang ahli, maka hakimlah yang menentukan ahli-ahli mana saja yang diperlukan untuk diperiksa guna untuk memberikan keteranganketerangan dalam persoalan-persoalan tertentu.

Namun pasal yang berkaitan dengan keterangan ahli dalam KUHAP tersebut hanya mengatur tentang alat bukti keterangan ahli secara singkat dan sederhana saja. Malahan Pasal 186 KUHAP hanya bersifat memberikan definisi terhadap apa yang dimaksudkan dengan istilah "keterangan ahli". Tidak ada keterangan lebih rinci seperti misalnya syarat apa saja sesorang bisa menjadi ahli ataupun kriteria dan indikator seperti apa jika sesorang dikatan ahli yang dapat dihadirkan didepan persidangan untuk dapat memberikan keterangan ahlinya. Kemudian bagaimana misalnya seorang hakim harus memperlakukan keterangan

1 Wisnubroto dan Widiartana, Pembaharuan Hukum Acara Pidana, Aditya Bakti, Bandung, 2005, hal 1. 


\section{$\mathcal{H}$ urnal Negara dan Keadilan \\ p-ISSN 2302-7010 e-ISSN 2721-9801}

ahli tersebut untuk menjadi dalil dalam pertimbangan hukum sebagai dasar putusannya.

\section{METODE PENELITIAN}

Penelitian ini dilakukan dengan jenis penelitian hukum yuridis normatif berupa penelitian kepustakaan yang menggunakan 3 bahan hukum yaitu bahan hukum primer, bahan hukum sekunder dan bahan hukum tersier. Penelitian hukum normatif memiliki definisi yang sama dengan penelitian hukum doktrinal yaitu penelitian berdasarkan bahan-bahan hukum yang fokusnya pada membaca dan mempelajari bahan hukum primer dan bahan hukum sekunder. ${ }^{2}$ Penelitian hukum ini menitikberatkan pada studi kepustakaan yang berarti akan lebih banyak menelaah dan mengkaji aturan-aturan hukum yang ada dan berlaku. Dalam penelitian ini memerlukan bahan hukum-bahan hukum karena akan berfungsi untuk melengkapi dan menunjang bahan hukum dalam penelitian kepustakaan (library research). Sedangkan pendekatan penelitian yang peneliti pergunakan dalam penelitian ini adalah pendekatan statute approach yaitu pendekatan peraturan perundang-undangan yang menitikberatkan pada bahan hukum primer yang mengatur tentang eksistensi keterangan ahli dalam sistem peradilan pidana di Indonesia.

\section{PEMBAHASAN}

Perkembangan istilah ahli saat ini sudah tidak lagi mengacu pada orangorang yang memiliki keahlian pada bidang ilmu yang diperoleh dari pendidikan formal saja, tetapi sebuah keahlian itu juga dapat berasal dari pengalaman dan praktik dalam masyarakat. Alat bukti keterangan ahli ditempatkan dalam urutan kedua sebagaimana yang disistematiskan dalam Pasal 184 KUHAP. Ini menunjukan bahwa alat bukti tersebut berpengaruh penting dalam pembuktian yang dimana penyidik, penuntut, maupun hakim belum jelas atau terang memandang suatu tindakan pidana ${ }^{3}$. Hal ini nentu menjadi sangat penting adanya aturan khusus mengenai ahli manakala dijadikan salah satu alat bukti yang sah dalam persidangan.

Pada prinsipnya, terdapat perbedaan antara keterangan ahli dengan keterangan saksi. Hal tersebut disebabkan karena segi penglihatan antara saksi dengan ahli berbeda. Pada saksi, maka ia harus menerangkan suatu peristiwa yang ia alami dan ia lihat atau ia dengar dengan mata kepala sendiri. Seorang saksi dalam memberikan keterangan, harus disertai dengan alasan atau sebab pengetahuan saksi, sebab awal sampai saksi dapat mengetahui peristiwa yang ia berikan keterangannya di sidang pengadilan. Sedangkan Keterangan Ahli diberikan oleh pihak ketiga yang objektif untuk memperoleh kejelasan dari suatu peristiwa dan memberikan pendapatnya didasarkan atas keahliannya. Maksud dari

2 Peter Mahmud Marzuki. Penelitian Hukum. Kencana Prenada Media Group, Jakarta, 2009. hal.93.

3 http://zulakrial.blogspot.com dalam "Problematika Keterangan Ahli Dalam Proses Peradilan Pidana" diakses tanggal 17 Februari 2017 Jam. 13:52 Wita. 


\section{Zurnal Negara dan $\mathcal{X}$ eadilan \\ p-ISSN 2302-7010 e-ISSN 2721-9801}

keterangan ahli ini adalah untuk membantu hakim dalam pemeriksaan guna menambah pengetahuan hakim itu dalam sesuatu hal tertentu.

Keterangan ahli mempunyai tujuan untuk memberikan keyakinan pada hakim dalam memberikan keterangan yang subjektif serta tidak memihak, maka keterangan ahli sering dipergunakan untuk membuktikan suatu perkara yang belum pasti kebenarannya. Dalam praktek, dimungkinkan keterangan ahli dipergunakan untuk memperkuat pertimbangan hakim dalam menjatuhkan putusan.

Pasal 180 KUHAP dapat dimaknai dalam posisi keterangan ahli dihadirkan dalam sidang pengadilan yang diminta oleh majelis hakim, maka hakim memiliki keyakinan akan sebuah perkara membutuhkan keterangan ahli untuk memberikan keterangan sesuai dengan keilmuan, pengalaman dan yang diketahuinya terkait dengan profesi yang dijalani seorang ahli. Hakim meyakini jika diperlukan keterangan ahli dapat dihadirkan, hal tersebut dapat memiliki alasan jika hadirnya ahli untuk membuat terang suatu perkara sehingga perkara yang diajukan ke pengadilan dapat terselesaikan.

Pengaturan keterangan ahli dalam HIR tidak ditegaskan dalam satu pasalpun, oleh karena keterangan ahli digabung dengan keterangan saksi. Padahal alat bukti tersebut adalah dua sisi yang berbeda. Keterangan saksi adalah keterangan yang diberikan oleh orang yang mengalami, melihat dan mendengar suatu peristiwa tindak pidana. Sedangkan keterangan ahli adalah keterangan yang diberikan oleh seorang ahli yang mempunyai pengetahuan khusus (keahlian/ expertise) yang dapat mendukung benar/ tidaknya telah teradi peristiwa tindak pidana. Pasal 186 KUHAP menegaskan bahwa keterangan ahli adalah apa yang seorang ahli nyatakan dalam persidangan. Dari uraian Pasal tersebut tidak menegaskan secara jelas, yang mana sesungguhnya dikatakan keahlian yang dimiliki oleh seorang yang dapat mendukung titik terang suatu tindak pidana. Kemudian, keterangan saksi ahli tidak hanya dapat digunakan dalam persidangan atau pembuktian guna mengungkap fakta-fakta baru dalam persidangan. Keterangan saksi ahlipun dapat digunakan/ diberikan oleh seorang saksi ahli baik dalam proses penyidikan, penuntutan, ataupun dihadirkan kembali ke dalam persidangan jika ketua majelis hakim menganggap penting untuk menghadirkan saksi ahli tersebut.

Persoalan yang kemudian muncul adalah bagaimana tentang indepedensi keterangan ahli yang diajukan baik oleh aparat penegak hukum atau oleh pihak tersangka/terdakwa dalam suatu perkara pidana, mengingat bahwa keterangan ahli hanya diberikan berdasarkan pada segi keilmuannya bukan pada apa yang ia lihat, dengar dan alami sendiri terhadap suatu tindak pidana.

Berbicara mengenai sikap independesi seorang ahli yang memberikan keterangan didepan persidangan misalnya seperti ahli dalam kasus pembunuhan Wayan Mirna Salihin oleh rekannya sendiri Jesika Komala Wongso. Baik ahli yang dihadirkankan oleh pihak Jesika ataupun pihak Jaksa Penuntut Umum (JPU) akan dipertanyakan independesinya (objektifitas) sekalipun sebelumnya mereka telah disumpah. Karena sesungguhnya masing-masing pihak yang berkepentingan diberikan hak untuk melakukan pembuktian, salah satunya dengan menghadirkan ahli untuk memberikan keterangan dipersidangan.

Kemudian persoalan yang juga muncul adalah bagaimana jika ahli yang dihadirkan adalah seorang ahli hukum. Padahal jika perpijak pada Undang-undang 


\section{Jurnal Negara dan Zeadilan \\ p-ISSN 2302-7010 e-ISSN 2721-9801}

Nomor 48 Tahun 2009 Tentang Kekuasaan Kehakiman, seorang hakim dianggap mengetahui hukum dan wajib menggali hukum, terlebih dalam peradilan pidana seorang hakim sifatnya aktif karena pada prinsipnya hakim akan mencari kebenaran materil. Berbeda halnya dengan peradilan perdata dimana seorang hakim bersifat pasif yang hanya mencari kebenaran formil.

Suatu keterangan ahli dapat bernilai sebagai alat bukti yang sah dengan melihat ketentuan Pasal 1 angka 28 KUHAP. Dikaitkan dengan ketentuan Pasal 184 ayat (1) huruf b KUHAP dan Pasal 186 KUHAP. Berdasarkan ketentuan dalam pasal-pasal tersebut, maka dapat dijelaskan lebih lanjut bahwa keterangan ahli harus merupakan keterangan yang diberikan oleh seseorang yang mempunyai keahlian khusus, tentang suatu yang ada hubungannya dengan perkara pidana yang sedang diperiksa. Sedangkan keterangan yang diberikan seorang ahli, tapi tidak mempunyai keahlian khusus tentang suatu keadaan yang ada hubungannya dengan perkara pidana yang bersangkutan, tidak mempunyai nilai sebagai alat bukti yang sah menurut undang-undang.

Tata cara dan bentuk keterangan ahli yang diberikan atau diminta di sidang pengadilan menurut M. Yahya Harahap adalah :

a. Apabila dianggap perlu dan dikehendaki baik oleh ketua sidang karena jabatannya, maupun atas permintaan penuntut umum, terdakwa atau penasihat hukum, dapat meminta pemeriksaan keterangan ahli dalam pemeriksaan di sidang pengadilan.

b. Keterangan ahli menurut tata cara ini berbentuk keterangan lisan dan secara langsung diberikan dalam pemeriksaan di sidang pengadilan.

c. Bentuk keterangan lisan secara langsung dicatat dalam berita acara pemeriksaan.

d. Dan untuk itu ahli yang memberikan keterangan lebih dahulu mengucap sumpah sebelum memberi keterangan.

e. Dengan dipenuhinya tata cara dan bentuk keterangan yang demikian, bentuk keterangan ahli tersebut menjadi alat bukti yang sah menurut undang - undang dan sekaligus keterangan ahli yang seperti ini mempunyai kekuatan pembuktian. ${ }^{4}$

Menempatkan keterangan ahli sebagai alat bukti yang sah di dalam pasal 184 ayat (1) huruf b KUHAP, dapat dicatat bahwa adanya kemajuan dalam pembaharuan hukum, bahwa sejalan dengan perkembangan teknologi, maka keterangan ahli memegang peranan penting dalam penyelesaian kasus pidana.

Masih kurangnya pengetahuan hakim dan penegak hukum lainnya dan arena minimnya alat bukti yang berkaitan dengan kemajuan teknologi informasi menjadikan sangat dibutuhkannya seorang ahli yang biasa meneliti kebenaran dari alat bukti tersebut dan hal ini sangatlah membantu proses persidangan.

Edmon Makarim dalam hal ini berpendapat sebagai berikut: Disinilah, peran seorang ahli dalam memberikan suatu penjelasan di depan pengadilan, bahwa data elektronik (hasil kemajuan teknologi informasi) adalah sah dan dapat dipertanggungjawabkan secara hukum. Standarisasi system tersebutlah yang menjadi sandaran berfikir bagi setiap argumentasi yang muncul di pengadilan.

${ }^{4}$ M. Yahya Harahap, Pembahasan Masalah dan Penerapan KUHAP (Pemeriksaan Sidang Pengadilan, banding, Kasasi dan Peninjauan kembali) Edisi ke2, Sinar Grafika, Jakarta, 2000, hal 297. 


\section{Hurnal Negara dan $\mathcal{X}$ eadilan \\ p-ISSN 2302-7010 e-ISSN 2721-9801}

Pertama kali seorang ahli akan mengecek apakah suatu system computer tersebut dapat dipercaya (trustworthy). Jika sebuah system dinyatakan sebagai dapat dipertanggungjawabkan dan dapat diajukan sebagai alat bukti / barang bukti yang memiliki kekuatan pembuktian yang sama dengan alat bukti lain yang ada di dalam Pasal 184 KUHAP. ${ }^{5}$

Pada prinsipnya alat bukti keterangan ahli tidak tidak mempunyai nilai kekuatan yang mengikat dan menentukan. Dengan demikian nilai kekuatan pembuktian keterangan ahli sama halnya dengan nilai kekuatan pembuktian yang melekat pada alat bukti keterangan saksi. Oleh karena itu, nilai kekuatan pembuktian yang melekat pada alat bukti keterangan ahli yaitu:

a. Mempunyai nilai kekuatan pembuktian bebas atau vrij bewijskrachf. Di dalam dirinya tidak melekat nilai kekuatan pembuktian yang sempurna dan menentukan. Terserah pada penilaian hakim hakim bebas menilai dan tidak terikat kepadanya. Tidak ada keharusan bagi hakim untuk mesti menerima kebenaran keterangan ahli dimaksud. Hakim dalam menggunakan wewenang kebenaran dalam penilaian pembuktian, harus benar-benar bertanggungjawab, atas landasan moral dan kebenaran sejati demi tegaknya hukum serta kepastian hukum.

b. Berlakunya prinsip minimum pembuktian pada keterangan ahli. Keterangan seorang saksi saja tidak cukup membuktikan kesalahan terdakwa, oleh Karena itu keterangan ahli dapat dianggap cukup membuktian kesalahan terdakwa harus disertai dengan alat bukti lain. ${ }^{6}$

KUHAP bukanlah satu-satunya undang-undang pidana formil yang mengatur mengenai ketentuan pembuktian. Beberapa Undang-Undang pidana yang mempunyai aspek formil juga mengatur mengenai alat bukti tersendiri yang diantaranya terdapat pengaturan alat bukti elektronik. Sistem ini menganut ajaran bahwa bersalah tidaknya-tidaknya terhadap perbuatan yang didakwakan, sepenuhnya tergantung pada penilaian "keyakinan" hakim semata-mata. Jadi bersalah tidaknya terdakwa atau dipidana tidaknya terdakwa sepenuhnya tergantung pada keyakinan hakim. Keyakinan hakim tidak harus timbul atau didasarkan pada alat bukti yang ada. Sekalipun alat bukti sudah cukup kalau hakim tidak yakin, hakim tidak boleh menjatuhkan pidana, sebaliknya meskipun alat bukti tidak ada tapi kalau hakim sudah yakin, maka terdakwa dapat dinyatakan bersalah.

Akibatnya dalam memutuskan perkara hakim menjadi subyektif sekali. Kelemahan pada sistem ini terletak pada terlalu banyak memberikan kepercayaan kepada hakim, kepada ken-kesan perseorangan sehingga sulit untuk melakukan pengawasan. Hal ini terjadi di praktik Peradilan Prancis yang membuat pertimbangan berdasarkan metode ini, dan banyak mengakibatkan putusan bebas yang aneh. ${ }^{7}$

Dalam konteks hukum acara pidana, pembuktian merupakan inti persidangan perkara pidana karena yang dicari dalam hukum acara pidana adalah

${ }^{5}$ Edmon Makarim, Kompilasi Hukum Telematika, PT Raja Grafindo Persada, Jakarta, 2004, hal. 435.

${ }^{6}$ Ibid. hal. 436.

${ }^{7}$ Andi Hamzah, Pengantar Hukum Acara Pidana Indonesia, Ghana Indonesia, Jakarta. 1985, hal, 241. 


\section{$\mathcal{H}$ urnal Negara dan Keadilan \\ p-ISSN 2302-7010 e-ISSN 2721-9801}

kebenaran materiil, yang menjadi tujuan pembuktian adalah benar bahwa suatu tindak pidana telah terjadi dan terdakwalah yang bersalah melakukannya.Untuk membuktikan kesalahan terdakwa, pengadilan terikat oleh cara-cara/ ketentuanketentuan pembuktian sebagaimana diatur dalam undang-undang.Pembukian yang sah harus dilakukan di dalam sidang pengadilan sesuai dengan prosedur/ cara-cara yang berlaku dalam hukum pembuktian.

Di dalam tata cara peradilan di Indonesia, pembuktian adalah salah satu dari tata cara peradilan Indonesia yang digunakan sebagai dasar pertimbangan hakim dalam mengambil sebuah keputusan hukum, yang didasarkan atas keyakinan hakim yang didasarkan kepada fakta-fakta yang telah di berikan oleh Jaksa Penuntut Umum dan juga Penasehat Hukum dan sang terdakwa itu sendiri, adapun keyakinan hakim yang akan terbentuk pada akhirnya nanti hanya terdiri dari dua macam, yaitu keyakinan bahwa terdakwa tidak terbukti bersalah atau sebaliknya keyakinan bahwa terdakwa terbukti bersalah.

Menurut M. Yahya Harahap pembuktian adalah ketentuan yang berisi penggarisan dan pedoman tentang cara-cara yang dibenarkan undang-undang membuktikan kesalahan yang didakwakan kepada terdakwa. Pembuktian juga merupakan ketentuan yang mengatur alat-alat bukti yang dibenarkan undangundang dan boleh digunakan hakim membuktikan kesalahan yang didakwakan. Namun secara umum alat bukti yang diatur dalam undang-undang pidana formil di luar KUHAP tersebut tetap merujuk pada alat bukti yang diatur dalam KUHAP. Pengaturan mengenai alat bukti yang diatur dalam undang-undang pidana formil di luar KUHAP hanya terbatas pada perluasan alat bukti terkait dengan UndangUndang Nomor 11 Tahun 2008 tentang Informasi dan Transaksi Elektronik (UU ITE).

Pada masa diberlakukannya Het Herzienne Inlands Reglement (HIR) sebagai pedoman hukum acara pidana di Indonesia, keterangan ahli tidak dikenal sebagai alat bukti tersendiri. Pasal 295 HIR menyebutkan alat-alat bukti yang sah terdiri dari kesaksian, surat-surat, pengakuan dan petunjuk-petunjuk.

Setelah KUHAP berlaku di Indonesia sebagai pengganti ketentuan hukum acara pidana dalam HIR, keterangan ahli termasuk menjadi salah satu alat bukti yang sah, hal ini terlihat pada Pasal 184 ayat 1 huruf b KUHAP. Selain di Indonesia, keterangan ahli juga menjadi salah satu alat bukti dalam hukum acara pidana modern di sejumlah negara, termasuk Belanda. ${ }^{8}$

Keterangan ahli sebagai alat bukti yang sah menurut Undang-Undang, dirumuskan dalam Pasal 186 KUHAP. Persoalan keterangan ahli terutama sebagai alat bukti tidak bisa dipahami hanya dengan bertumpu pada Pasal 186 KUHAP. Uraian Pasal 186 yang tidak diikuti rincian lebih lanjut mengenai keterangan ahli dalam pasal-pasal selanjutnya tidak mampu menjelaskan masalah yang dikandungnya. Untuk memahami keterangan ahli sebagai alat bukti, maka diperlukan penjajakan lebih lanjut atas ketentuan-ketentuan yang terkait dengan keterangan ahli yang terpencar dalam pasal-pasal KUHAP.

Pasal 1 angka 28 KUHAP memuat pengertian keterangan ahli yaitu keterangan yang diberikan oleh seseorang yang memiliki keahlian khusus tentang hal yang diperlukan untuk membuat terang suatu perkara pidana guna kepentingan

${ }^{8}$ Andi Hamzah. Hukum Acara Pidana Indonesia. Sinar Grafika, Jakarta. 2001, hal. 267 


\section{Jurnal Negara dan $\mathcal{X}$ eadilan \\ p-ISSN 2302-7010 e-ISSN 2721-9801}

pemeriksaan. Gagasan utama dari upaya pencarian bukti dengan meminta keterangan ahli adalah membuat terang tindak pidana.

Keterangan ahli dapat juga sudah diberikan pada waktu pemeriksan oleh penyidik atau penuntut umum yang dituangkan dalam suatu bentuk laporan dan dibuat dengan mengingat sumpah di waktu ia menerima jabatan atau pekerjaan. Jika hal itu tidak diberikan pada waktu pemeriksaan, maka di sidang diminta untuk memberikan keterangan dan dicatat dalam berita acara pemeriksaan. Keterangan tersebut diberikan setelah ia mengucapkan sumpah atau janji dihadapan hakim. Jadi dengan demikian keterangan ahli diberikan setelah ia mengucapkan sumpah atau janji di hadapan hakim dan juga keterangan ahli itu diperlukan untuk membuat terang suatu perkara pidana guna kepentingan pemeriksaan baik itu pemeriksaan yang dilakukan oleh penyidik maupun pemeriksaan yang dilakukan di pengadilan.

Pada prinsipnya alat bukti keterangan ahli tidak mempunyai kekuatan pembuktian yang mengikat dan menentukan. Dengan demikian, nilai kekuatan pembuktian keterangan ahli sama halnya dengan nilai pembuktian yang melekat pada alat bukti keterangan ahli. Oleh karena itu, nilai kekuatan pembuktian yang melekat pada alat bukti keterangan ahli yaitu:

a. Mempunyai nilai kekuatan pembuktian "bebas" atau vrij bewijskracht". Didalam dirinya tidak ada melekat nilai kekuatan pembuktian yang sempurna dan menentukan. Terserah pada penilaian hakim. Hakim bebas menilainya dan tidak terikat kepadanya.

b. Disamping itu sesuai dengan prinsip minimum pembuktian yang diatur dalam Pasal 183 KUHAP, keterangan ahli yang berdiri sendiri saja tanpa didukung oleh salah satu alat bukti yang lain, tidak cukup dan tidak memadai membuktikan kesalahan terdakwa. Apalagi jika Pasal 183 KUHAP di hubungkan dengan ketentuan Pasal 185 ayat (2) KUHAP, yang menegaskan, seorang saksi saja tidak cukup untuk membuktikan kesalahan terdakwa.

Keterangan ahli adalah merupakan alat bukti dalam suatu proses peradilan perkara pidana sebagaimana diatur dalam Pasal 184 ayat (1) KUHAP. Terkait dengan keterangan ahli itu sebagai alat bukti, ia hanya akan menjadi alat bukti bagi Penuntut Umum saja ketika seorang ahli memberikan keterangan pada saat penyidikan. Suatu keterangan ahli sebagai alat bukti yang sah dan menjadi pertimbangan bagi hakim dalam memutus suatu perkara pidana adalah ketika keterangan ahli itu disampaikan dalam persidangan. Hal ini sesuai dengan ketentuan Pasal 186 KUHAP yang mengatakan bahwa keterangan ahli ialah apa yang seorang ahli nyatakan di sidang pengadilan. Karena itu, keterangan ahli yang diberikan ahli pada waktu penyidikan dan menjadi bahan bagi Penuntut dalam menyusun dakwaan, harus diberikan ahli dalam persidangan. Konsekuensinya, bisa keterangan yang diberikan ahli dalam persidangan, lebih terinci dan tidak tertutup kemungkinan pendapat ahli itu mendapat pengujian dalam persidangan baik oleh hakim, penuntut umum maupun penasihat hukum terdakwa. ${ }^{9}$

Sesuai dengan kedudukan dan apa yang dimaksud dengan keterangan ahli sebagai alat bukti, ia sekaligus menjadi pembeda dengan keterangan saksi. Karena itu dalam berbagai kesempatan sering kita dengar istilah "saksi Ahli" adalah suatu

\footnotetext{
${ }^{9} \mathrm{http} / / / \mathrm{www}$. boyyendratamin.com/2016/08/kedudukan-keterangan-ahli-sebagai-alat.html diakses tanggal 25 Juni 2017 jam 10.45 WITA.
} 


\section{Jurnal Negara dan Zeadilan \\ p-ISSN 2302-7010 e-ISSN 2721-9801}

kekeliruan, karena secara hukum "ahli" dan "saksi" dari sisi alat bukti adalah dua hal yang berbeda. Secara singkat keberadaan ahli dalam persidangan mengarah pada pendapat ahli atas sesuatu menurut keahlian ahli, sedangkan saksi sebagai alat bukti mengarah kepada apa yang dilihat, dirasakan dan dialami saksi atas suatu peristiwa pidana. Keterangan ahli adalah berupa pendapat berdasarkan keilmuan yang dimiliki ahli, sedangkan keterangan saksi menuju pada fakta. Itulah sebabnya, mengapa kepada seorang saksi tidak boleh ditanyakan pendapatnya atas sesuatu terkait suatu perkara pidana. Sebaliknya pada ahli, ia tidak boleh memberikan keterangan atas fakta, melainkan pendapatnya atas sesuatu terkait dengan masalah perkara pidana tengah periksa.

Jadi keberadaan seorang ahli dalam pemeriksaan suatu proses peradilan perkara pidana adakalanya diperlukan dan adakalanya tidak. Hal itu tergantung dari bentuk dan jenis perkara pidananya. Keperluan akan keterangan ahli sebagai contoh bisa ditemukan dalam KUHAP sendiri. Pasal 133 ayat (1) KUHAP.

Dari dua ketentuan KUHAP di atas, maka keberadaan keterangan ahli sebagai alat bukti pada prinsipnya berkedudukan untuk menguatkan suatu elemen atau unsur suatu tindak pidana, khususnya atas tindak-tindak pidana yang untuk memastikanya membutuhkan keterangan dari seorang yang memiliki keahlian khusus terkait dengan unsur tindak pidana bersangkutan. Hal itu tentu berarti juga, keterangan ahli sebagai alat bukti yang sah tidak menjadi alat bukti utama berupa keterangan saksi yang memberikan keterangan atas fakta dari suatu perbuatan pidana. Artinya, ketika keterangan saksi sebagai alat bukti tidak ada, maka suatu tindak pidana bisa dinyatakan dengan hanya berdasarkan keterangan ahli saja. Atau keterangan ahli lebih menjadi pertimbangan utama dalam memutus suatu perkara pidana, ketika keterangan saksi lemah.

Sekalipun sama-sama berkedudukan sebagai alat bukti, namun kedudukan keterangan ahli sebagai alat bukti tidak dapat menggantikan atau didorong menjadi alat bukti utama dalam sebuah perkara pidana. Hal ini sesuai dengan keberadaan keterangan ahli dalam lingkup memberikan keterangan bukan mengenai apa yang dilihat, dialami dan dirasakan ahli atas terjadinya suatu tindak pidana, melainkan keterangan atau pendapat ahli berdasarkan keahliannya mengenai hal-hal yang ada hubungannya dengan perkara yang tengah diperiksa.

Dengan demikian, dalam sebuah pemeriksaan perkara pidana, seorang ahli yang dihadirkan dalam persidangan memerlukan pula pengetahuan secara hukum tentang kedudukan dan ruang lingkup keterangannya sebagai ahli dalam sebuah persidangan. Seorang ahli dalam memberikan keterangan dalam satu persidangan perkara pidana harus memiliki pemahaman yang memadai atas keterangan yang akan diberikannya, karena bisa jadi ahli terjebak memberikan keterangan seolaholah keterangan yang diberikannya tidak obahnya keterangan "saksi". Kemungkinan ahli memberikan keterangan layak keterangan seorang saksi bisa berasal dari diri ahli sendiri, bisa pula terjadi karena ketidakmapuannya menyaring pertanyaan yang diajukan hakim, penuntut umum maupun penasehat hukum.

\section{PENUTUP}

Keterangan ahli sebagai alat bukti yang sah dirumuskan dalam Pasal 186 KUHAP. Persoalan keterangan ahli terutama sebagai alat bukti tidak bisa dipahami hanya dengan bertumpu pada Pasal 186 KUHAP. Uraian Pasal 186 yang 


\section{Hurnal Negara dan $\mathcal{X}$ eadilan \\ p-ISSN 2302-7010 e-ISSN 2721-9801}

tidak diikuti rincian lebih lanjut mengenai keterangan ahli dalam pasal-pasal selanjutnya tidak mampu menjelaskan masalah yang dikandungnya. Untuk memahami keterangan ahli sebagai alat bukti, maka diperlukan penjajakan lebih lanjut atas ketentuan-ketentuan yang terkait dengan keterangan ahli yang terpencar dalam pasal-pasal di dalam KUHAP. Pada prinsipnya alat bukti keterangan ahli tidak mempunyai kekuatan pembuktian yang mengikat dan menentukan. Nilai kekuatan pembuktian keterangan ahli sama halnya dengan nilai pembuktian yang melekat pada alat bukti keterangan ahli. Dalam perkataan lain, keterangan ahli adalah berupa pendapat berdasarkan keilmuan yang dimiliki ahli, sedangkan keterangan saksi menuju pada fakta.

\section{Buku}

\section{DAFTAR PUSTAKA}

Andi Hamzah, 1985, Pengantar Hukum Acara Pidana Indonesia, Jakarta: Ghana Indonesia. 2001. Hukum Acara Pidana Indonesia. Jakarta: Sinar Grafika

Edmon Makarim, 2004, Kompilasi Hukum Telematika, Jakarta: PT Raja Grafindo Persada.

M. Yahya Harahap, 2000, Pembahasan Masalah dan Penerapan KUHAP (Pemeriksaan Sidang Pengadilan, banding, Kasasi dan Peninjauan kembali) Edisi ke2, Jakarta: Sinar Grafika

Peter Mahmud Marzuki. 2009. Penelitian Hukum. Jakarta: Kencana Prenada Media Group.

Wisnubroto dan Widiartana, 2005, Pembaharuan Hukum Acara Pidana, Bandung: Citra Aditya Bakti.

\section{Internet}

Http://zulakrial.blogspot.com dalam "Problematika Keterangan Ahli Dalam Proses Peradilan Pidana" diakses tanggal 17 Februari 2017 Jam. 13:52 Wita.

Http://www.boyyendratamin.com/2016/08/kedudukan-keterangan-ahli-sebagaialat.html diakses tanggal 25 Juni 2017 jam 10.45 WITA. 